\title{
The Effect of Stock Ownership Toward the Corporate Social Responsibility (CSR) Disclosure
}

\section{Heni Nurani Hartikayanti and Ifan Wicaksana Siregar}

Faculty of Economics and Business, Universitas Jenderal Achmad Yani Bandung, Indonesia

\section{Abstract}

This study aims at investigating the effect of stock ownership by foreign parties and government toward the level of corporate social responsibility (CSR) disclosure. The participating companies of Indonesia Sustainability Reporting Awards 2015 were selected as the samples by employing purposive sampling technique. This study employed secondary data from annual report, sustainability report, and financial report. Data were analyzed using simple linear regression analysis. The result shows

Corresponding Author: Heni Nurani Hartikayanti heni.nurani@lecture.unjani.ac.id

Received: 29 August 2018 Accepted: 18 September 2018 Published: 11 November 2018

Publishing services provided by Knowledge E

(c) Heni Nurani Hartikayanti and Ifan Wicaksana Siregar. This article is distributed under the terms of the Creative Commons Attribution License, which permits unrestricted use and redistribution provided that the original author and source are credited.

Selection and Peer-review under the responsibility of the ICOI-2018 Conference Committee.

\section{G OPEN ACCESS} that government and foreign ownership had no significant influence toward CSR disclosure.

Keywords: government ownership, foreign ownership, Indonesia sustainability, reporting awards, corporate social responsibility

\section{Introduction}

The impact of the company's operations on its environment has been widely expressed in different parts of the world. This environmental impact can either be positive and negative. Some countries have established rules that require companies to allocate certain amount of money to finance shared activities for environmental use (Caroll, 1991). Expenditure on environmental costs is known as corporate social responsibility. Corporate Social Responsibility (CSR) is a company's activity to build the environment and must be disclosed in the annual report, not only based on the single bottom line consisting of corporate value, but also on the triple bottom lines consisting of finance, social and environment (Caroll, 1991; Machmud and Djakman, 2008). In the Law Number 40 of 2007 on Limited Liability Company, Article 74 Paragraph 1 that "Companies that carry out their business activities in the field and/or related to natural resources shall carry out social and environmental responsibility". Implementation of CSR has been seriously taken into account as the issuance of Government Regulation (PP) No. 
47 of 2012 on Corporate Social Responsibility and Environment of Limited Liability Company. This regulation stipulates that companies that do not manage and do not utilize natural resources, but whose business activities affect the functions of natural resource capability including the preservation of environmental functions, are also required to implement CSR and include it in the company's annual report. CSR disclosure conducted by the company has to be included in the sustainability report as one component of the annual report presented by the company. Graaf land (2006) states that CSR practices and disclosures are closely related to Good Corporate Governance (GCG). Companies must comply with existing regulations and take into account the interests of its stakeholders and establish cooperation with other stakeholders for the long-term company viability. In the ISRA 2015, there was a phenomenon where the level of CSR disclosure conducted by the ISRA participants did not reach one hundred percent, but only between the range of fifty percent or below of fifty percent. This can be affected by several factors, one of which is stock ownership.

\section{Literature Review}

The main principle of agency theory states the existence of a working relationship between the party giving authority (principal) and its agents (manager). Jensen and Mackling (1986) argue that agency relationships are a contract in which one or more people (principals) involve another person (agent) to perform some services on their behalf that involve delegating some decision-making authority to the agent. In an agency relationship, there are three influencing factors on the CSR disclose, namely: supervision cost, contract cost, and political visibility. When companies face contract costs and low oversight fees and high political visibility will tend to disclose social information (Belkaoui, 1989).

The discussion of CSR is inseparable from the theory of legitimacy, shareholders and firm perspective. Lindblom (1994) explains that the theory of legitimacy attempts to explain why a company makes social and environmental disclosures. The theory of legitimacy reveals that companies continually strive to act in accordance with the limits and norms in society. Through these efforts, the company seeks to have its activities accepted according to the perception of external parties (Deegan, 1996). Chariri (2008) explains that the theory of legitimacy is beneficial in analyzing organizational behavior, because the theory of legitimacy is the most important thing for the organization. 
In the view of stakeholder theory, companies also have stakeholders, not just shareholders (Belkaoui, 1989). Stakeholders are parties who have an interest in the company, have a business commitment to contribute to sustainable development. Thus, the existence of a company is strongly influenced by the support provided to the company (Chariri, 2008). Furthermore, according to Freeman (1999), the community is the most important stakeholder for the company and the media plays an important role in communicating the activities of the company to the stakeholders. Therefore, companies need to apply the principles of good corporate governance and Corporate Social Responsibility to maintain reputation in front of its stakeholders. Stakeholders are grouped into two: primary stakeholders and secondary stakeholders (Freeman 1994). Primary stakeholders consist of shareholders, owners, investors, employees and customers. Meanwhile, secondary stakeholders are stakeholders that influence or indirectly influenced by corporate strategy such as government, public, and the environment.

Based on the classification of stakeholders, foreign ownership is included in the primary stakeholders group because foreign ownership is a form of ownership other than institutional ownership and managerial ownership. Companies that have contractual relationships with foreign stakeholders in both ownership and trade will be fully supported to practice CSR in their environment. The company's effort to bind the stakeholders is not easy, because the company cannot know one by one the desires of its stakeholders (Caroll, 1991). One of the corporate strategies that can be done by managers is by disclosing Corporate Social Responsibility (CSR) in annual report, which will be useful for investors as one of the stakeholders to oversee company performance and to assess the extent to which the company perform its role in accordance with the wishes of stakeholders. If the company performs CSR disclosure properly, then the value of the company will also increase. Government share ownership is the number of stocks owned by the government. Through ownership of these stocks, the government is entitled to establish the director of the company. In addition, the government can control the policies taken by management to suit the interests or aspirations of the government (Lovink, 2014). One of the factors affecting the extent of disclosure of a company's annual report is the basis of the company. The government has the right to appoint the director of the company so that the business decisions taken are an extension of the government's interest (Amran et al., 2008).

Foreign ownership is the percentage of share ownership by foreign investors that is considered as a party that has a high awareness of CSR program. According to Law no. 25 of 2007 on Article 1 Point 6, foreign ownership is an individual foreign citizen, 
foreign business entity, and foreign government with capital in the territory of the Republic of Indonesia. Multinational companies or with foreign ownership primarily see the benefits of legitimacy derived from its stakeholders, typically based on the home market (market that operates) that can provide a long existence in the long run (Suchman, 1995). Foreign ownership in Indonesia is divided into two types: the ownership of stocks(trade) and the addition of subsidiaries (ownership). Companies with foreign ownership should provide more disclosure than those who do not because (1) foreign companies get better training in accounting from overseas holding companies; (2) the company may have a more efficient information system to meet the internal needs and the holding company needs; and (3) the possibility of greater demand for foreign-based enterprises from customers, suppliers and the general public.

In Indonesia, Corporate Social Responsibility has evolved since the issuance of Law No. 23 of 1997 on Environmental Management. It shows that the government has also concerned this issue. According to The World Business Council for Sustainable Development (WBCSD), Corporate Social Responsibility is a business commitment to contribute to sustainable economic development, through collaboration with employees and their representatives, their families, local communities and the general public to improve life in a way that is beneficial for both business and development. According to International Standard ISO 26000 (2010), Corporate Social Responsibility is the responsibility of an organization as the impact of a decision and its social and environmental activities, through transparent and ethical conducts that contribute to sustainable development, health and welfare of the community; taking into account the expectations of the stakeholders; in accordance with applicable law and consistent with international behavioral norms and integrated throughout the organization and practiced in a relationship. The rationale of Corporate Social Responsibility based on business ethic that the company does not only have economic obligations to shareholders, but also social obligations to stakeholders, namely government, community, customers, investors and even competitors company. Stakeholder theory believes that companies should carry out social disclosure as one of the responsibilities of corporate responsibility to the stakeholders. In recent years, CSR is no longer just a formality in corporate activities, but rather an important obligation especially in business strategy. Mishra (2010) and Bahman et al. (2014) state there are several benefits of Corporate Social Responsibility for the company, such as: (1) maintaining and enhancing the company's reputation and brand image; (2) obtaining a license to operate socially; (3) reducing the business risk of the company; (4) expanding access to resources for the company's operations; (5) opening up a wider market; (6) reducing costs, e.g. related 
to the impact of waste disposal; (7) improving relationships with stakeholders and

regulators; (8) increasing employee morale and productivity; (9) getting opportunity to get award. In the long run, CSR will become a strategic and competitive asset for corporations amidst a business climate that demands ethical and responsible business practices. It is necessary to have a continuous evaluation of CSR implementation by the company (Miriam, 2016).

Many researchers have conducted studies on the company's share ownership towards the broad range of CSR disclosure. In harmony with stakeholder theory, ownership of the company's stocks of institutional ownership, public, foreign, family, management and government. The results of research on the effect of institutional ownership on the level of CSR disclosure have been widely practiced in several countries (Robert, 1992; Mohamed et al., 2012; Mukhtarudin, 2014; Yongjia, 2017; Mahoney, 2007; Wahaba, 2015; Hartikayanti, 2015; Isabelle et al., 2015). The institutional ownership in this study is generally owned by a company. The results showed there were different results. Some have claimed that institutional ownership affected CSR disclosure, but some other studies suggest otherwise.

The influence of foreign stock ownership (in this case non-residents of a country) generally showed a positive influence on CSR disclosure (Moustafa, 2012; Darus et al., 2013; Dalilawati, 2013). Other studies have stated different results that foreign ownership had no significant effect (Hartikayanti, 2016; Winarti, 2014, Sufian, 2013; Machmud and Djakman, 2008). Studies on the effect of government stockownership on the level of CSR disclosure by some researchers showed a low effect (Qing Hua, 2016), and a positive effect (Winarti, 2013).

\section{Methods}

There were504 companies listed in Indonesia Stock Exchange in 2015. There were 39registered companies as the participants of Indonesia Sustainability Reporting Award (ISRA) in 2015. Meanwhile, there were16 companies reported their CSR activities. The sampling was done by employing purposive sampling technique (Sugiyono, 2013). The collected data were in the form of secondary data that were derived from the annual financial statements and the disclosure of CSR from participant companies of ISRA 2015.Data were analyzed using normality test, multicollinearity, heteroscedasticity test, and auto correlation test. The hypothesis testing was done using simple regression (Sugiyono,2013). 


\section{Results and Discussion}

The average percentage of foreign share ownership ranged from $46.8 \%$. The CSR disclosure data was based on the $\mathrm{G}_{4}$ Global Reporting Initiative (GRI) standard consisting of 91 assessment items grouped in 46 aspects with 6 performance indicators. According to the overall aspect that should be disclosed by the company, all of the sample companies only revealed up to the $50 \%$.

TABLE 1: Correlation Between Foreign Ownership and CSR Disclosure.

\begin{tabular}{|l|l|c|c|}
\hline & & $\begin{array}{c}\text { Foreign } \\
\text { Ownership }\end{array}$ & CSR Disclosure \\
\hline Foreign Ownership & Pearson Correlation & 1 & -.323 \\
& Sig. (2-tailed) & & .223 \\
\cline { 2 - 4 } & $\mathrm{N}$ & 16 & 16 \\
\hline CSR Disclosure & Pearson Correlation & -.323 & 1 \\
\cline { 2 - 4 } & Sig. (2-tailed) & .223 & 16 \\
\hline
\end{tabular}

The data processing results above shows that the level of relationship between these two variables was low with negative direction. Moreover, the relationship that occurred between the two variables in this study was not significant, so this study shows that the direction was not significantly negative.

TABLE 2: The Influence of Foreign Ownership on Level of CSR Disclosure.

\begin{tabular}{|l|c|c|c|c|}
\hline Model & $\mathrm{R}$ & R Square & $\begin{array}{c}\text { Adjusted R } \\
\text { Square }\end{array}$ & $\begin{array}{c}\text { Std. Error of } \\
\text { the Estimate }\end{array}$ \\
\hline 1 & $.323^{a}$ & .104 & .040 & .12112 \\
\hline
\end{tabular}

The above table shows that the value of determination coefficient was $10.4 \%$. This value shows that corporate social responsibility disclosure $10.4 \%$ rate could be explained by foreign ownership variable. Meanwhile, the remaining $89.6 \%$ could be explained by other causes outside the model or other variables that were not examined in this study.

The above test results show that the value of $t$ arithmetic for foreign ownership variable means there was no significant influence between foreign ownership of corporate social responsibility disclosure. Foreign ownership is a variable that has been widely used as an independent variable in various studies. The foreign party is considered to be concerned about CSR disclosure. European countries and the United States are seen having more concerned on social and environmental issues such as human rights 
TABLE 3: Significance of the Influence of Foreign Ownership on Level of CSR Disclosure.

\begin{tabular}{|c|c|c|c|c|c|c|}
\hline \multicolumn{7}{|c|}{ Coefficients $^{a}$} \\
\hline \multicolumn{2}{|c|}{ Model } & \multicolumn{2}{|c|}{ Unstandardized Coefficients } & \multirow{2}{*}{$\begin{array}{c}\text { Standardized } \\
\text { Coefficients } \\
\text { Beta }\end{array}$} & \multirow[t]{2}{*}{$\mathrm{T}$} & \multirow[t]{2}{*}{ Sig. } \\
\hline & & $B$ & Std. Error & & & \\
\hline \multirow[t]{2}{*}{1} & (Constant) & .411 & .059 & & 6.973 & .000 \\
\hline & $\begin{array}{l}\text { Foreign } \\
\text { Ownership }\end{array}$ & -.124 & .097 & -.323 & -1.275 & .223 \\
\hline
\end{tabular}

violations, education, labor, and environmental issues such as greenhouse effect, wild burning, and water pollution.

Foreign ownership is more tied to agency theory stating that foreign parties are considered as a concern to CSR disclosure will encourage the management as the party who runs the company's activities to disclose the activities of corporate social responsibility and foreign ownership in the company able to make the monitoring process better. Information owned by the management can be provided by the company's stakeholders. Foreign ownership is an appropriate control mechanism to reduce agency conflict as it can improve the company's oversight process. However, in this study, foreign ownership showed that foreign ownership had no significant effect on corporate social responsibility disclosure. This means that the size of the foreign shareholding would not affect the disclosure of corporate social responsibility. The argument that foreign stock ownership is concerned with social and environmental issues that will encourage corporate management to conduct CSR activities and increase CSR disclosure, was not proven in this study. The large differences in foreign share holdings did not guarantee that firms with greater foreign ownership would disclose more corporate social responsibility information than firms with small foreign shareholdings.

TABLE 4: Relationship of Government Ownership and Level of CSR Disclosure.

\begin{tabular}{|c|c|c|c|}
\hline \multicolumn{4}{|c|}{ Correlations } \\
\hline & & $\begin{array}{l}\text { Government } \\
\text { Ownership }\end{array}$ & CSR Disclosure \\
\hline \multirow[t]{3}{*}{$\begin{array}{l}\text { Government } \\
\text { Ownership }\end{array}$} & $\begin{array}{l}\text { Pearson } \\
\text { Correlation }\end{array}$ & 1 & -.192 \\
\hline & Sig. (2-tailed) & & .549 \\
\hline & $\mathrm{N}$ & 12 & 12 \\
\hline \multirow[t]{3}{*}{ CSR Disclosure } & $\begin{array}{l}\text { Pearson } \\
\text { Correlation }\end{array}$ & -.192 & 1 \\
\hline & Sig. (2-tailed) & .549 & \\
\hline & $\mathrm{N}$ & 16 & 16 \\
\hline
\end{tabular}


The above data processing results show that the level of relationship between these two variables was very low and showed a significant negative value between the two variables and each increase in government ownership would-be accompanied by a decrease in CSR disclosure of the company. The results also showed that the relationship between the two variables in this study was not significant, so the direction was not significantly negative.

TABLE 5: Influence of Government Ownership with Level of CSR disclosure.

\begin{tabular}{|c|c|c|c|c|}
\hline \multicolumn{5}{|c|}{ Model Summary ${ }^{b}$} \\
\hline Model & $\mathrm{R}$ & R Square & $\begin{array}{l}\text { Adjusted R } \\
\text { Square }\end{array}$ & $\begin{array}{l}\text { Std. Error of the } \\
\text { Estimate }\end{array}$ \\
\hline 1 & $.192^{a}$ & .037 & -.059 & .18943 \\
\hline \multicolumn{5}{|c|}{ a. Predictors: (Constant), Government Ownership } \\
\hline \multicolumn{5}{|c|}{ b. Dependent Variable: CSR Disclosure } \\
\hline
\end{tabular}

The above data shows a small value so it can be concluded that a regression model is appropriate to be used to predict the dependent variable. The smaller the value of SEE will make the regression model more precise in predicting the dependent variable. The test results above table can be seen that there was no significant influence between government ownership of CSR disclosure. Government ownership was more tied to agency theory stating that larger companies will require greater disclosure to reduce information asymmetry with principals. The results also show that government ownership had no significant effect on CSR disclosure. The results of this study is in accordance with Meilissa's (2014) research. This means that CSR disclosure has not been implemented optimally. The results show that the size of government ownership in a company did not affect the CSR disclosure of the company. If viewed from the analysis of the above data, it can be concluded that the ownership of stock by foreign parties and the government did not affect the breadth of CSR disclosure.

\section{Conclusion}

In Indonesia, the obligation to disclosure corporate social responsibility on environment has been established in law. In fact, the company owners, in this case the shareholders, have not complied with the law. With the authority they possess, companies may be encouraged to disclose their social responsibility obligations to their environment by complying with established laws. The result of data analysis shows that there was no influence of share ownership, either by government or by foreign party, on the CSR 
disclosure. There was also no difference of social responsibility fulfillment obligation between companies whose stocks are owned by foreign party or government.

\section{References}

[1] Amran, Azlan., Susela Devi, (2008) "The Impact of Government and Foreign Affiliate Influence on Corporate Social Reporting in Malaysia." Accounting, Auditing and Accountability Journal, Volume Vol, 23, No.4, pp. 356-370

[2] Belkaoui, Ahmed., Philip G Karpik, (1989) "Determinants of the Corporate Decision to Disclose Social Information", Accounting, Auditing and Accountability Journal, Vol. 2, No. 1,PP 36- 51

[3] Carroll, A.B. (1991) "The Pyramid of Corporate Social Responsibility: Toward the Moral Management of Organizational Stakeholders". Business Horizons. Edisi JuliAgustus 1991. hal 39-48.

[4] Chariri, A. (2008). "Organizational Culture and Financial Reporting Practice in an Indonesian Insurance Company". The 14th Euro-Asia Conference and The 3rd International Conference on Business and Management Research (ICBMR) Denpasar, Bali. 27-29 Agustus 2008.

[5] Dalilawati Zainal., Suria Zainuddin, (2013),Corporate Social Responsibility Reporting In Malaysia: A Research Note, Journal of Accounting Perspectives, Vol. 6, pp. 21-36

[6] Deegan, Craig., Michaela Rankin. (1996). "Do A Australian Companies Report Environmental News Objectively? An Analysis of Environmental Disclosures Firms Prosecuted Successfully by the Environmental Protection Authority". Accounting Auditing and Accountability Journal.

[7] Faizah Darus, Engku Artini Che Ku Hamzah, Haslinda Yusoff (2013),CSR Web Reporting: The Influence of Ownership Structure and Mimetic Isomorphism, Procedia Economics and Finance 7,pp. $236-242$

[8] Freeman, R.E., 1994, The Politics of Stakeholder Theory: Some Future Directions, Business Ethics Quarterly, Vol. 4/4, Pp. 409-421.

[9] Freeman, R.E., 1999, Divergent Stakeholder Theory, Academy of Management Review, Vol. 24/2, pp.233-236.

[10] Global Reporting Initiative.(2014) Sustainability Reporting Guidelines.

[11] Graaf land, J. dan Bert van de Ven. (2006) "Strategic and Moral Motivation for CSR". The Journal of Corporate Citizenship. Vol. 22. No.1,hal 111-123.

[12] Hartikayanti, Heni Nurani, Dessy Maryani (2015), The Influence Of Industry Profile, Growth Opportunities, And Public Ownership Due To The Corporate Social 
Responsibility Disclosure, International Journal Of Applied Business and Economic Research, Vol. 13, No. 7, pp. 5845-5868

[13] Hartikayanti, Heni Nurani, M. Ryan Trisyandi dan ER Budhi S, (2016) Effect of Corporate Characteristics on Environmental Disclosure, International Journal of Applied Business and Economic Research, Vol. 14. No.10. pp. 6111-6134

[14] Hayam Wahba, Khaled Elsayed. (2015). The mediating effect of financial performance on the relationship between social responsibility and ownership structure, FutureBusiness)ournal,pp.1-12

[15] Isabelle Ducassya, Sophie Montandrau. Ducassy, S. Montandrau,(2015), Corporate social performance, ownership structure, and corporate governance in France, Research in International Business and Finance 34, pp.383-396

[16] Lindblom, C. K. (1994), "The Implications of Organizational Legitimacy for Corporate Social Performance and Disclosure", Critical Perspectives on Accounting Conference, New York.

[17] Lois Mahoney, Robin W. Roberts (2007), Corporate social performance, financial performance and institutional ownership in Canadian firms, Accounting Forum 31,pp. 233-253

[18] Machmud dan Djakman. (2008). "Pengaruh Struktur Kepemilikan terhadap Luas Pengungkapan Tanggung Jawab Sosial (CSR Disclosure) pada Laporan Tahunan Perusahaan: Study Empiris pada Perusahaan Publik yang Tercatat di Bursa Efek Indonesia 2006." Simposium Nasional Akuntansi 11.

[19] Mackling, William H. and Jensen, Michael C. 1976, "Theory of the Firm: Managerial Behavior, Agency Costs and Ownership Structure", Journal of Financial Economics (JFE), Vol. 3,No. 4, pp. 305-360

[20] Miriam Jankalova (2016), Approaches to the evaluation of Corporate Social Responsibility, Procedia Economics and Finance 39, Pp. $580-587$

[21] Mohamed Moustafa Soliman, Mohamed Bahaa El Din, and Ahmed Sakr (2012), Ownership Structure And Corporate Social Responsibility (CSR): An Empirical Study of The Listed Companies In Egypt, International Journal of Social Sciences Vol 5 No 1, pp. $63-74$

[22] Mukhtaruddin, Relasari, Messa Felmina (2014). Good Corporate Governance Mechanism, Corporate Social Responsibility Disclosure on Firm Value: Empirical Study on Listed Company in Indonesia Stock Exchange. International Journal of Finance \& Accounting Studies. Vol. 2 No. 1 pp. 135-166.

[23] Peraturan Pemerintah No. 47 Tahun 2012 Tentang Tanggung Jawab Sosial dan Lingkungan Perseroan Terbatas (PT). 
[24] Pour, Bahman Saeidi, Kamran Nazari, Mostafa Emami (2014). Corporate social responsibility: A Literature review. African Journal of Business Management. Vol. 8 (7) pp. 228-234.

[25] Qinghua Zhu, Junjun Liu, Kee-hung Lai, Zhuetal (2016).,Corporate social responsibility practices and performance improvement among Chinese national state-owned enterprises. Int. J. Production Economics 171,pp.417-426

[26] Republik Indonesia. (2007) Undang-undang No. 40 Tahun 2007 tentang Perseroan Terbatas. Departemen Hukum dan Hak Asasi Manusia Republik Indonesia.

[27] Roberts, R.W. (1992) "Determinants Of Corporate Social Responsibility Disclosure: An Application Of Stakeholder Theory". Accounting, Organisations and Society. Vol. 17 No. 6. pp. 595-612.

[28] Suchman, M. C. (1995) "Managing Legitimacy: Strategic and Institutional Approaches", Academy of Management Journal, Vol. 20, No. 3, pp. 571 - 610.

[29] Sufian, Mohammad Abu, Muslima Zahan (2013). Ownership Structure and Corporate Social Responsibility Disclosure In Bangladesh. International Journal of Economics and Financial Issues Vol. 3 No. 4 Pp 901-909.

[30] Sugiyono. 2016. Metode Penelitian Bisnis. Bandung: Alfabeta

[31] Supriti Mishra, Damodar Suar. 2010. Does Corporate Social Responsibility Influence Firm Performance Of Indian Companies? Journal of Business Ethics (2010) 95. pp. 571-601.

[32] Undang Undang No. 23 Tahun 1997 tentang Pengelolaan Lingkungan Hidup

[33] Winarti, 2013, Pengaruh Kepemilikan Pemerintah (BUMN) Dan Kepemilikan Asing Terhadap Luas Pengungkapan Tanggungjawab Sosial Perusahaan Pada Laporan Tahunan Perusahaan, Jurnal TEKUN Volume IV, No.02, pp. 305-316

[34] Yongjia Rebecca Lina, Xiaoqing Maggie Fub (2017),Does institutional ownership influence firm performance? Evidence from China, International Review of Economics and Finance 49,pp. 17-57 